\title{
Clinical Results of Minimally Invasive Graft Harvesting from the Anterior Iliac Crest: Description of a Novel Technique
}

\section{Anterior Iliak Crest'ten Minimal Invazif Greft Alımının Klinik Sonuçları: Yeni Bir Tekniğin Tanımı}

\author{
Onur Bilge ${ }^{1,2}$, Ismail Hakki Korucu, ${ }^{1, *}$, Faik Turkmen ${ }^{1}$, Nazim Karalezli $^{3}$
}

${ }^{1}$ Necmettin Erbakan University, Meram Faculty of Medicine, Department of Orthopaedics and Traumatology, Konya, Turkey

${ }^{2}$ Necmettin Erbakan University, Meram Faculty of Medicine, Department of Sports Medicine, Konya, Turkey

${ }^{3}$ Hand Surgery, Private Clinic of Orthopaedics and Traumatology, Mugla, Turkey

Address correspondence to: Ismail Hakki Korucu, Necmettin Erbakan University, Meram Faculty of Medicine, Department of Orthopaedics and Traumatology, Konya, Turkey

e-mail: drihkorucu@gmail.com

Geliş Tarihi/Received: 5 July 2021 Kabul Tarihi/Accepted: 25 August 2021
Öz

Amaç: Otolog kemik greft kullanımı çeşitli ortopedik girişimlerde altın standarttır. Bu çalışmanın amacı, anterior iliak krestten Jamshidi ile K-teli kılavuzlu, çok yönlü perkütan kemik grefti almanın alternatif bir tekniğini tanıtmak ve bu tekniğin erken karşılaştırmalı klinik sonuçlarını ortaya koymaktır. Hastalar ve Yöntem: Bu retrospektif karşılaş̧ırmalı çalışmaya Ocak-Kasım 2013 tarihleri arasında kemik grefti gerektiren çeşitli el ameliyatları geçiren 38 hasta dahil edildi. Hastaların dahil edilen tanıları; el ve bilek kemiği kırıkları psödoartrozları ve iyi huylu kemik tümörleriydi. Hastaların prospektif olarak toplanan verileri geriye dönük olarak iki grupta değerlendirildi. İliak krest otogreft alımı, sırasıyla grup I ve II'de standart bir açık teknikle ve sonraki bölümde anlatılacak olan yeni bir perkütan teknikle gerçekleştirildi. Hastaların ortalama yaşı sırasıyla grup I ve II'de $29,6+/-6,4$ ve $28,6+/-8,2$ idi. Hastaların postoperatif ağrı ve cerrahi yara izi algısına bağlı ağrıları Görsel Analog Skala üzerinden derecelendirilmiş; postoperatif 6 . ayda kaydedildi. Istatistiksel olarak Mann-Whitney U testi kullanıldı.

Bulgular: Perkütan grupta hiçbir majör postoperatif komplikasyon görülmedi. Ağrı açısından, postoperatif 6 . ayda orta vadede VAS skorları grup II'de grup l'e göre anlamlı olarak düşük bulundu $(p<0.05)$.

Sonuç: Iliak krestten Jamshidi ile yeni K-teli kılavuzlu kemik grefti toplama, postoperatif ağrı azaltma açısından güvenli ve hasta dostu bir yöntemdir. Bu teknik, kemik grefti gerektiren küçük eklem ve kemik ameliyatlarında faydalıdır. Bu çalışmanın sonuçları, daha yüksek düzeyde kanıt çalışmaları ile daha da desteklenmelidir.

Anahtar Kelimeler: Anterior iliak krest, kemik grefti toplama, perkütan, minimal invaziv

\section{Abstract}

Aim: Autologous bone harvesting is the gold standard for grafting in a variety of orthopaedic procedures The aims of this study were to introduce an alternative technique of K-wire guided, multidirectional percutaneous bone graft harvesting with Jamshidi from the anterior iliac crest, and to put forward the early comparative clinical results of this technique.

Patients and Methods: 38 patients, who underwent a variety of hand surgeries in which bone grafting was required between January and November 2013, were included in this retrospective, comparative study. The included diagnoses of the patients were; non-unions of hand and wrist bone fractures, and benign bone tumors. The prospectively collected data of patients were retrospectively evaluated in two groups. Iliac crest autograft harvesting were performed with a standardized open technique, and with a novel percutaneous technique -which will be described in the subsequent section- in group I, and II, respectively. The mean age of the patients was $29.6+/-6.4$, and $28.6+/-8.2$ in group I, and II, respectively. The patients postoperative pain related with the perception of the pain and surgical scar, were evaluated according to the graded Visual Analogue Scale; at postoperative 6th months. Statistically, Mann-Whitney U test was used. Results: There were no major postoperative complications in the percutaneous group. Regarding pain, mid-term at postoperative 6th months, VAS scores were found to be lower in group II than in group I, significantly $(p<0.05)$.

Conclusion: The novel K-wire guided bone graft harvesting with Jamshidi from the iliac crest is a safe and patient-friendly method in terms of postoperative pain reduction. This technique is useful in small joint and bone surgeries, requiring bone grafting. The results of this study should be further supported with higher level of evidence studies.

Key words: Anterior iliac crest, bone graft harvesting, percutaneous, minimally invasive
Cite this article as: Bilge $\mathrm{O}$, Korucu IH, Turkmen F, Karalezli N. Clinical Results of Minimally Invasive Graft Harvesting from the Anterior Iliac Crest: Description of a Novel Technique. Selcuk Med J 2021;37(3): 263-268
Disclosure: None of the authors has a financial interest in any of the products, devices, or drugs mentioned in this article. The research was not sponsored by an outside organization. All authors have agreed to allow full access to the primary data and to allow the journal to review the data if requested. 


\section{INTRODUCTION}

Autologous bone is the gold standard harvested material for grafting in a variety of orthopaedic procedures; such as delayed unions, non-unions, bony defects due to trauma, infection, tumor or congenital conditions, and situations requiring bony fusion (1). This is mainly due to the fact that autologous bone is the only graft that contains all fundamental components of the diamond concept of the regenerative medicine and more: osteogenicity (mesenchymal stromal cells), osteoinductivity (growth factors), osteoconductivity (scaffold), and optimum skeletal incorporation (1-5). The main limiting factors for the use of autografts are the amount of availability, and the host morbidities $(6,7)$.

The most common sites for autologous bone graft harvesting have been the ilium, and the fibula (1). The donor site complications of autologous bone harvesting from the iliac bone can be classified as minor and major complications (8-14). Minor complications of bone harvesting from the ilium include cosmetic problems, superficial infections, superficial seromas, minor hematomas. On the other hand, major complications include persistent donor site pain, deep hematomas, deep infections, iliac bone perforation, peritoneal perforation, herniation of the abdominal contents through defects in the iliac bone, urethral injuries, iliac wing / pelvic fractures, sacroiliac joint / pelvic instability, hip subluxation, gait disturbances, vascular injuries, neurological injuries, chronic pain, and numbness.

As open techniques for graft harvesting carry relatively higher risk of significant morbidity and complications; adequate preoperative planning, awareness of the anatomy, and careful surgical technique should be applied, and moreover, minimally invasive percutaneous techniques may be performed in selected cases of especially hand surgeries, alternatively, in order to avoid or to minimize these risks (8,9,11,15-18). Alternatively, other materials, which have also been used in the regenerative medicine, such as allografts, non-biological synthetic bone substitutes, further carry the risks of high cost, infection, immunologically-mediated inflammatory reactions, rapid resorption, etc. $(4,6,7)$. Another recently frequently used alternative -especially for larger volume of graft requirements- is the use of reamer irrigation aspirate (RIA), which has also its specific advantages, and disadvantages (19-21).

The aims of this study were to introduce an alternative technique of $\mathrm{K}$-wire guided, multidirectional percutaneous bone graft harvesting with Jamshidi from the anterior iliac crest and to demonstrate early comparative clinical results of this technique.

\section{PATIENTS AND METHODS}

In this retrospective, comparative study, 38 patients who underwent a variety of hand surgeries in which bone grafting was required between January and November 2013, were included. The included diagnoses of the patients were; non-unions of hand and wrist bone fractures, and benign bone tumors. Malignant tumors, revision cases, and patients with hematological, cardiovascular, neurological diseases and previous deformities related with bone and soft tissues at the surgical site were excluded. The prospectively collected data of patients were retrospectively evaluated in two groups. Iliac crest autograft harvesting were performed with a standardized open technique, and with a novel percutaneous technique -which will be described in the subsequent section- in group I, and II, respectively.

\section{Percutaneous Surgical Technique}

The patients were operated in supine position, and under general anesthesia, by elevating the hemipelvis with an underlying sand bag in order to make the anterior ilium prominent. The surgical instruments, used in the percutaneous technique, are demonstrated in Figure 1.

After surgical antibiotic prophylaxis, standardized preparation and anatomical marking of the surgical sites, a $0.5 \mathrm{~cm}$ mini-incision of the entry site is made by passing at least $4 \mathrm{~cm}$ posterior to the anterior

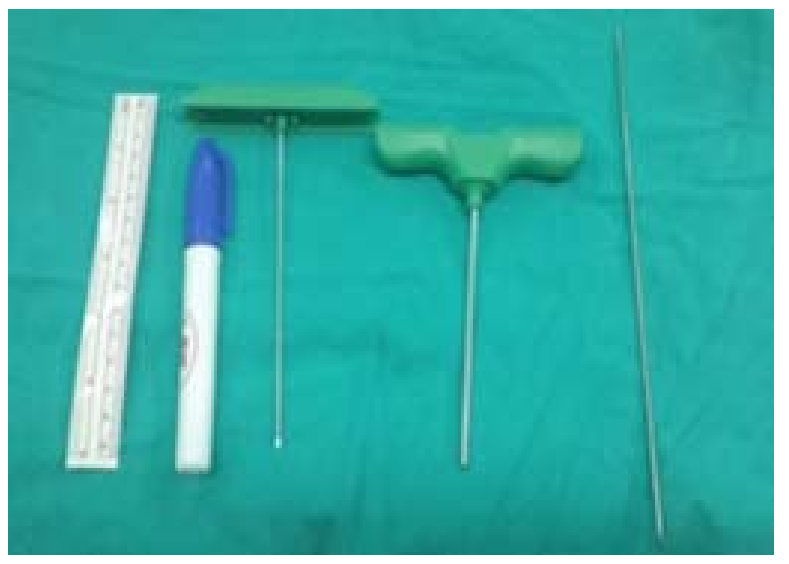

Figure 1. Surgical instruments used for percutaneous guided graft harvesting from the anterior iliac crest: ruler, board marker, Jamshidi (inner \& outer parts), K-wire 


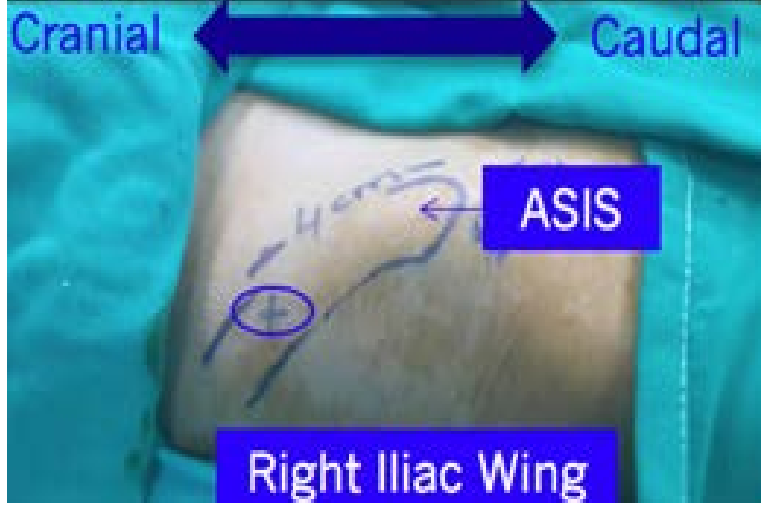

Figure 2. Surgical installation and standard anatomical markings of the entry site for percutaneous graft harvesting from the right anterior iliac crest (x); at least $4 \mathrm{~cm}$ posterior to the ASIS. (ASIS: Anterior superior iliac spine)

superior iliac spine, in order to protect lateral femoral cutaneous nerve (Figure 2). The outer sleeve of Jamshidi is oriented properly according to the inner and outer cortices of the iliac wing (Figure 3). The $\mathrm{K}$-wire is introduced inside the outer sleeve of the Jamshidi, and advanced with a motorized drill in order penetrate the superior cortex of the anterior iliac wing, as a trajectory guide for Jamshidi (Figure 3). The outer sleeve of Jamshidi is advanced manually over the K-wire guide (Figure 4). The multidirectional harvesting is possible repeatedly, if required more (Figure 5). The amount of harvested grafts is

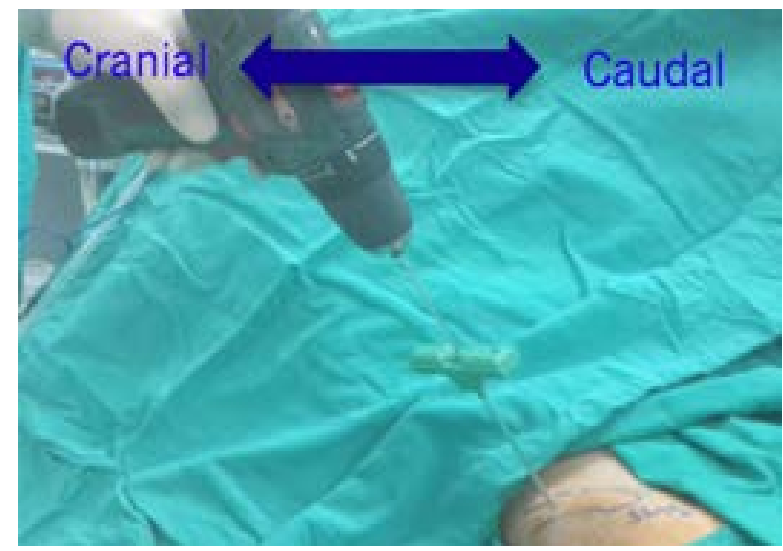

Figure 3. Proper orientation of the outer sleeve of Jamshidi according to the inner and outer cortices of the iliac wing, and introduction and advancement of a K-wire with a motorized drill inside the outer sleeve of the Jamshidi for penetration of the superior cortex of the iliac wing, as a guide for Jamshidi.

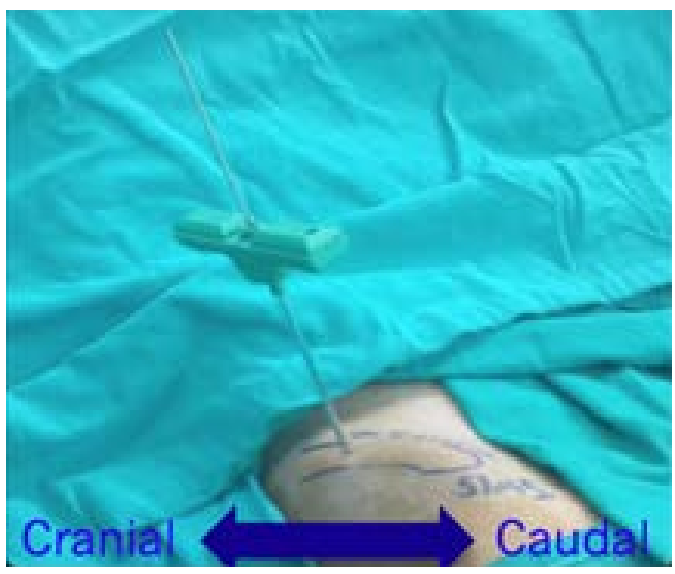

Figure 4. Advancement of the outer sleeve of Jamshidi over the K-wire guide.

determined by the size of the primary surgical site (Figure 6).

\section{Clinical and Statistical Evaluation}

The patients' postoperative pain related with the perception of the pain and surgical scar, were evaluated according to the graded Visual Analogue Scale; \pm at postoperative 6th month. Statistically, Mann-Whitney $U$ test was used. Statistical significance was set at $p$ values $<0.05$

\section{RESULTS}

The mean age of the patients was $29.6 \pm 6.4$, and $28.6 \pm 8.2$ in group I, and II, respectively. The male to female number was $19(16 \mathrm{M} / 3 \mathrm{~F})$, and $19(15 \mathrm{M} / 4$ $\mathrm{F}$ ) in group I, and II, respectively. There were no major
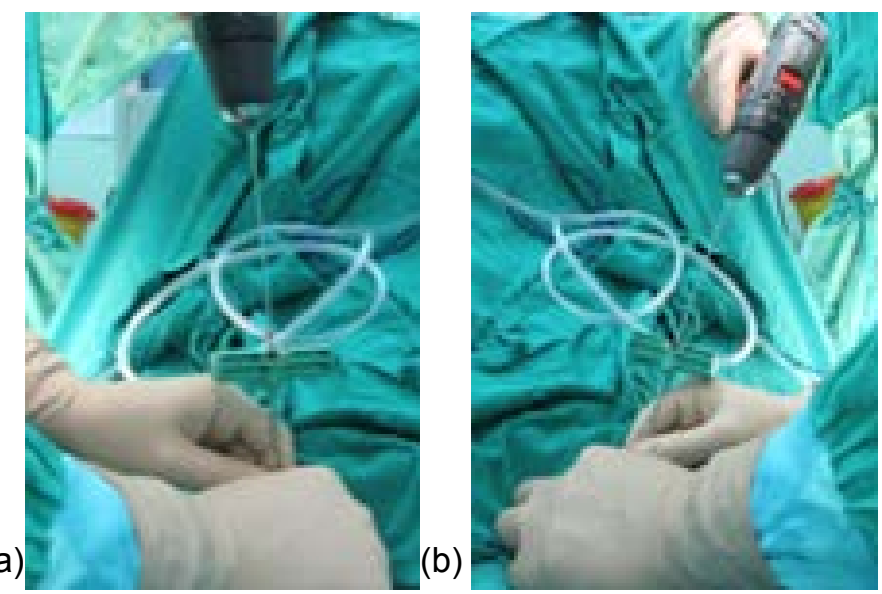

Figure 5. ( $a$ and $b$ ) Multidirectional harvesting possible repeatedly, as required. 


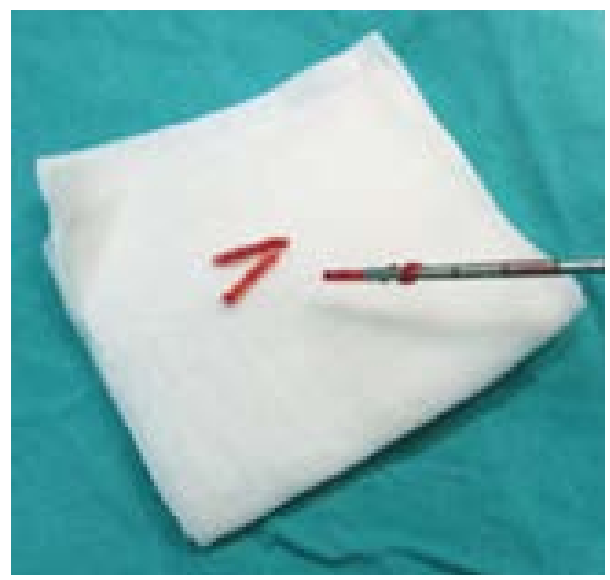

Figure 6. Harvested autografts ready for use.

postoperative complications, or no non-union, in all patients at final follow-up of 6 months. On one hand, cortical perforation and retroperitoneal hematoma were developed in a patient in the group I. On the other hand, there was even no minor complication in the group II. Regarding pain mid-term at postoperative 6th months, VAS scores were found to be lower in group II than in group I, significantly (Table 1).

\section{DISCUSSION}

The most important result of this study was that the use of newly-described K-wire guided percutaneous bone graft harvesting from the iliac crest yielded successful clinical results in terms of postoperative pain and morbidity, when compared with the open technique. This alternative percutaneous technique is useful in small joint and bone surgeries, which requires relatively low volume of bone grafting. The gold standard bone grafting material has been accepted as the autologousbone, mainly due to its osteoinductive, osteogenetic and osteoconductive properties, and increased skeletal incorporation (1,2$5)$. The main limiting factors for the use of autografts are the amount of availability, and the donor site morbidities $(6,7)$.

To minimize the limitations of the use of autografts, other materials such as allografts, non-biological synthetic bone substitutes, and a recently frequently used alternative, RIA were introduced with specific advantages, and disadvantages. Allografts, and synthetic bone substitutes carry the risk of high cost, infection, immunologically-mediated inflammatory reactions, rapid resorption, etc. $(4,6,7)$. RIA, which has been used for larger volume grafting with shorter harvest time, less donor site pain, and similar union rates compared with iliac crest bone grafting, carry the risks of cortical bone perforation, and donor femur fracture $(3,19-21)$. The latter risks can be minimized with the careful application of the surgical technique. But, this high-volume of grafting technique is not necessary for grafting in small bones.

The most common site for harvesting autologous bone graft is the iliac crest, compared with other alternative sites distal radius, distal femur, fibula, olecranon, and ribs. It has some advantages and complications. Firstly, the advantages of iliac crest are as follows; easy access, availability of a large amount of all kinds of bone graft (cancellous, cortical, corticocancellous, tricortical and vascularized) (4). Secondly, although the most common complications were reported to be the chronic donor site pain and sensory disturbances, others include infection, hematoma, neurovascular injuries, fractures, herniations, poor cosmesis, hypertrophic scars, etc., which are broadly classified as major and minor complications, depending on the severity or the necessity of further treatment. (22-24).In a meta-analysis of Dimitriou et al. (24), the rates of major and minor complications were found to be reported as $0.76-25 \%$, and 10 $39 \%$, respectively. In the same meta-analysis, the estimated morbidity rate was reported as $19.37 \%$.

Anterior and posterior iliac crests are amenable to graft harvesting. On one hand, posterior iliac crest is mostly used for spinal surgeries, on the other hand anterior iliac crest is used for mostly surgeries of the extremities. In a study of Ahlmann et al. (22) posterior iliac crest bone graft harvesting was reported to have lower postoperative complication rates. But, anterior iliac crest fractures tend to be more stable and to heal spontaneously in most cases, compared with posterior iliac crest fractures, which require more complex

Table 1. Mean values of VAS scores at postoperative 1st day, and at postoperative 6 th months.

\begin{tabular}{lll}
\hline Mean values +/- SD & VAS Score Early postop. (1st day) & VAS Score Mid-term postop. (6th months) \\
\hline Group I (Open) & $8.64+/-0.91$ & $3.22+/-0.70$ \\
Group II (Percutaneous) & $2.40+/-0.85$ & $1.05+/-0.38$ \\
$\left(^{*}\right): p<0.05$ & $\left(^{*}\right)$ & $\left(^{*}\right)$ \\
\hline
\end{tabular}


surgical treatments and often lead to significant further disabilities (14). In the meta-analysis of Dimitriou et al. (24), the complication rates and overall differences in morbidity of these two donor sites were found to be similar, as statistically insignificant. In the same metaanalysis, specific recommendations were also made to reduce morbidity of iliac crest bone graft harvesting.

Regarding the technique of iliac crest bone graft harvesting; the main aim of percutaneous techniques was to decrease the morbidity, and complications (e.g. cortical perforation, iliac wing fracture, hematoma, etc.), which were more commonly encountered with open techniques (24-26). In the same studies, the advantages of various percutaneous techniques are well-established, especially in terms of donor site pain and cosmetics. Moreover, apart from the results of these studies, our study results demonstrated that this newly described K-wire guided-percutaneous graft harvesting from anterior iliac crest had the subsequent advantages; alternative minimal invasive technique, possible multidirectional graft harvesting, minimizing the risk of iatrogenic cortical perforation, and subsequent complications, significant comparative clinical improvement in grafting for smallmedium sized bone and joint surgeries, and possible application to other graft donor sites.

This study has also several drawbacks to be discussed. Firstly, the results of this study were retrospectively evaluated. But, this was the first description of the new K-wire guided percutaneous technique of bone graft harvesting, which was performed in order to minimize the morbidities related with open technique. Moreover, the data was collected prospectively. Secondly, the number of patients in both groups was relatively small. But, a statistical significance was found between the two groups. Thirdly, the surgeries were performed by multiple surgeons. But, all the surgeons used the same standardized aforementioned technique in all surgeries. Fourthly, although complications related with graft harvesting are commonly encountered in cases where large amount of graft is required, minimally invasive techniques are not complication free. Lastly, the quantification of grafts was not performed necessarily in this study, as the amount of grafts could be determined visually as required in relatively small surgical areas.

\section{CONCLUSION}

This novel K-wire guided-percutaneous bone graft harvesting from the anterior iliac crest is a safe and patient-friendly method in terms of postoperative pain reduction, when compared with open technique. This technique is clinically successful and useful in small joint and bone surgeries, in which bone grafting is required. Higher level of evidence studies are also required.

Conflict of interest: Authors declare that there is no conflict of interest between the authors of the article.

Financial conflict of interest: Authors declare that they did not receive any financial support in this study.

Address correspondence to: Ismail Hakkı Korucu, Necmettin Erbakan University, Meram Faculty of Medicine, Department of Orthopaedics and Traumatology, Konya, Turkey

e-mail: drihkorucu@gmail.com

GSM: 905422925898

\section{REFERENCES}

1. Ebraheim NA, Elgafy $H, X u$ R. Bone-graft harvesting from iliac and fibular donor sites: Techniques and complications. J Am Acad Orthop Surg 2001;9(3):210-8.

2. Calori GM, Colombo M, Mazza EL, et al. Monotherapy vs. polytherapy in the treatment of forearm nonunions and bone defects. Injury 2013;44(Suppl. 1):63-9.

3. Calori GM, Colombo M, Mazza EL, et al. Incidence of donor site morbidity following harvesting from iliac crest or RIA graft. Injury 2014;45:116-20.

4. Bauer TW, Muschler GF. Bone graft materials. An overview of the basic science. Clin Orthop Relat Res 2000;371:10-27.

5. Urist MR, McLean FC. Osteogenic potency and new-bone formation by induction in transplants to the anterior chamber of the eye. J Bone Joint Surg Am 1952;34A:443-76.

6. Betz RR. Limitations of autograft and allograft: New synthetic solutions. Orthopedics 2002;25(5 Suppl):561-70.

7. Finkemeier CG. Bone grafting and bone-graft substitutes. J Bone Joint Surg 2002;84A(3):454-64.

8. Arrington ED, Wmith WJ, Chambers HG, et al. Complications of iliac crest bone harvesting. Clin Orthop Relat Res 1996;329:300-9.

9. Kurz LT, Garfin SR, Booth RE Jr. Harvesting autogenous iliac bone grafts. A review of complications and techniques. Spine (Phil Pa 1976) 1989;14(12):1324-31.

10. Seiler JG 3rd, Johnson J. Iliac crest autogenous bone grafting: Donor site complications. J South Orthop Assoc 2000;9(2):91-7.

11. Fowler BL, Dall BE, Rowe DE. Complications associated with harvesting autogenous iliac bone graft. Am J Orthop (Belle Mead NJ) 1995;24(12):895-903.

12. Velchuru VR, Satish SG, Petri GJ, et al. Hernia through an iliac crest bone graft site: Report of a case and review of the literature. Bull Hosp Jt Dis 2006;63(3-4):166-8.

13. Chan K, Resnick D, Pathria M, et al. Pelvic instability after bone graft harvesting from posterior iliac crest: Report of nine patients. Skeletal radiol 2001;30(5):278-81.

14. Nocini PF, Bedogni A, Valsecchi $S$, et al. Fractures of the iliac crest following anterior and posterior bone graft harvesting. 
Review of the literature and case presentation. Minerva Stomatol 2003;51(10):441-8.

15. Goulet JA, Senunas LE, DeSilca GL, et al. Autogenous iliac crest bone graft. Complications and functional assessment. Clin Orthop Relat Res 1997;339:76-81.

16. Sandor GK, Rittenberg BN, Clokie CM, et al. Clinical success in harvesting autogenous bone using a minimal invasive trephine. J Oral Maxillofac Surg 2003;61(2):164-8.

17. Sandor GK, Nish IA, Carmichael RP. Comparison of conventional surgery with motorized trephine in bone harvest from anterior iliac crest. Oral Surg Oral Med Oral Pathol Radiol Endod 2003;95(2):150-5.

18. Lopez GD, Hijji FY, Narain AS, et al. Iliac crest bone graft: A minimally invasive harvesting technique. Clin Spine Surg 2017;30(10):439-41.

19. Dawson J, Kiner D, Gardner W, et al. The reamer-irrigatoraspirator as a device for harvesting bone graft compared with iliac crest bone graft: Union rates and complications. J Orthop Trauma 2014;28(10):584-90.

20. Hernigou P, Desroches A, Queinnec S, et al. Morbidity of graft harvesting versus bone marrow aspiration in cell regenerative therapy. Int Orthop 2014;38(9):1855-60.
21. Marchand LS, Rothberg DL, Kubiak EN, et al. Is this autograft worth it? The blood loss and tansfusion rates associated with reamer irrigator aspirator bone graft harvest. J Orthop Trauma 2017;31(4):205-9.

22. Ahlmann E, Patzakis M, Roidis N, et al. Comparison of anterior and posterior iliac crest bone grafts in terms of harvest-site morbidity and functional outcomes. J Bone Joint Surg Am 2002;84-A(5):716-20.

23. Younger EM, Chapman MW. Morbidity at bone graft donor sites. J Orthop Trauma 1989;3(3):192-5.

24. Dimitriou R, Mataliotakis GI,Angoules AG, et al. Complications following autologous bone graft harvesting from the iliac crest and using the RIA: A systematic review. Injury Int J Care Injured 2011;42:3-15.

25. Missiuna PC, Gandhi HS, Farrokhyar F, et al. Anatomically safe and minimally invasive transcrestal technique for procurement of autogenous cancellous bone graft from the mid-iliac crest. Can J Surg 2011;54(5):327-32.

26. Atac MS, Kilinc Y, Bozkaya S. Evaluation of bone graft harvesting techniques from anterior ilium. J Craniofac Surg 2014;25(4):1418-21. 